\title{
一般化異構造マスタスレーブシステムの 可操作性解析*
}

\author{
岸元 邦充 $^{\dagger} \cdot$ 石川 将人 ${ }^{\dagger} \cdot$ 大須賀公一 $^{\dagger}$
}

\author{
Manipulability Analysis for Dissimilar Master-slave Systems \\ with Different Degrees-of-freedom*
}

Kunimitsu Kishimoto ${ }^{\dagger}$, Masato IshikawA ${ }^{\dagger}$ and Koichi OsukA ${ }^{\dagger}$

\begin{abstract}
In this paper, we suggest to apply artificial nonholonomic mechanical constraints to masterslave manipulation systems, so that the slave system can be operated by a dissimilar master system with relatively less numbers of degree-of-freedom. The cost for this reduction of degree-of-freedom, in general, should be compensated by skillful (or temporally complicated) operation of the master system. For this purpose, we propose an extended definition of manipulability considering the nature of small-time controllability of nonholonomic systems, and derive its numerical analysis as well. The proposed approach is illustrated with numerical simulations.
\end{abstract}

\section{1.はじめに}

非ホロノミック拘束とは, 一般化座標の等式条件で表 すことのできない, 積分不可能な力学的拘束のことであ る.非ホロノミック拘束をもつシステムは , 周期入力の ような適切な入力を加えることによって，状態空間にお いて瞬間的には遷移できない方向に対しても間接的に遷 移させることが可能である. 兴のため入力変数よりも多 くの数の状態変数を操作できるということが知られてお り, さかんに研究が行われている [1] .

非ホロノミック系の制御の研究の多くは拘束の存在下 における制御問題の難しさに焦点が当てられているが， 一方で炎の制御構造の特徵を長所として積極的に用いる ことを試みた研究もいくつかある.荒井ら [2] は, 状態 変数の非線形等価変換を用いて, 人間が直感的に操作し にくい非ホロノミック系である平面宇宙ロボットの姿勢 制御を，経験的に操作し慣れている非ホロノミック系で ある車両系の操作に置き換えることで, 兴の操作性が改 善されることを示している．また石川 [3] は，複数の車 輪型移動ロボットをすべて独立に制御するのに必要な入 力よりも少ない数の入力であっても，適切に入力を割り

\footnotetext{
* 原稿受付 2011 年 12 月 27 日

$\dagger$ 大阪大学 大学院 工学研究科 Graduate School of Engineering, Osaka University; 2-1 Yamada-oka, Suita, Osaka 565-0871, JAPAN
}

Key Words: master-slave system, manipulability, nonholonomic system, nonlinear controllability, reachable set.
当てることによって各ロボットの位置や姿勢を任意の目 標值に到達させることができることを示している . 非ホ ロノミック拘束が入力変数以上の数の状態変数を任意に 操作できるひとつの顕著な例として, 非ホロノミック拘 束を用いた非ホロノミック・マニピュレータが中村らに よって考案されている $[4,5]$.これは非ホロノミックな転 がり接触を利用した動力伝達装置を用いることで, アク チュエータの数より多くの関節角度を任意に制御できる というものである .

さて, 人間が機械システムを操作する方式の典型的な ものとしてマスタスレーブシステム (以下 MSS と略す) が広く用いられている.これは操作者か指示したマスタ アームの運動にならうようにスレーブアームの運動を制 御するシステムであり, スレーブアームとマスタアーム が機構的に同じ構造のものを同構造 MSS , 異なるものを 異構造 MSS という. 異構造 MSS についてもマスタアー ムの操作性やスレーブアームの作業性の向上を目的とし ていくつかの研究がなされている $[6,7]$ が, 通常はスレー ブの自由度がマスタの自由度を上回ることは考えられて いない .ここで, 非ホロノミックシステムをオペレータ による操縦系と捉えたとき, システムが非線形の意味で 可制御であれば, 操作者は入力よりも多数の自由度をも つスレーブを操作できることになる .すなわち, 通常の MSS では操縦側であるマスタと被操縦側であるスレー ブの自由度が 1 対 1 (几長マニピュレータでは多対 1 ) と 考えられてきたのに対し, 運動自由度の減少・増大を含 
めて任意に変換できる新しいMSS を考えることができ る. 本研究ではこれを一般化異構造マスタスレーブシス テムとよゔ. 非ホロノミック拘束を操縦系に(機械的に あるいはソフトウェア的に) 導入すれば，たとえば，マ スタアームの入力に対して冗長な自由度をもつスレーブ アームを光の先端の到達位置だけでなく中間関節の形状 まで含めて制御したり，後述するように 2 本の操縦桿に よる入力だけで 3 本以上の腕の姿勢を独立意に制御する といったことが可能になる .このような MSS は , 操作 者である人間の身体構造に起因する操作自由度の限界を 拡張するシステムであるといえ, 多数・多自由度の制御 対象を一人で操ることにより，従来の MSS では不可能 であった，もしくは困難であった作業をより効率的に行 うことができる可能性が期待できる .

ただし当然ながら，マスタ側の自由度を節約するとい うメリットは，より熟練した操作が必要になるというコ ストとなって返ってくる．乥れが車両系の操作のように 許容できるものであるかどうかはシステムによって異な るため，「操作しやすさ」を定量的に評価する必要があ る . 同構造の MSS ではマニピュレータの可操作性の概 念が一つの操縦性指標となるが，これは瞬間的な状態変 化の自由度を捉えたものであって，兴のままでは非ホ口 ノミック拘束を含む系には適さない，光こで本論文では，

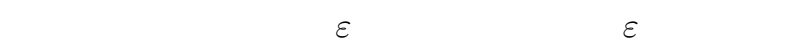
タとして表したものを可操作性概念の一般化とすること を提案し $(\varepsilon=0$ のとき従来の可操作性と一致する $)$, 光 の数值解析の方法についても考察する.

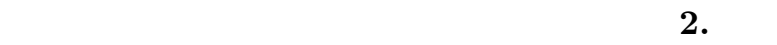
一般化異構造 MSS の発想を適用例とともに述べ, 弚の

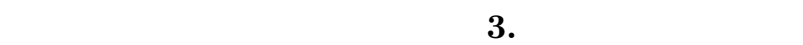
夕の評価指標として広く用いられている可操作性の概念 の導入と非ホロノミック拘束を含む系への適用可能性に ついて議論し，一般化異構造 MSSに適した新しい評価 指標として，可操作性に制御時間 $\varepsilon$ 導入によって拡張 したものを提案する . 4. では 3. で設定した指標とシス テムの入力の関係を , 非ホロノミック系の典型例である Brockett integratorについて解析し，兴の特性を考察す る . 5. では本論文のまとめと今後の課題について述べる .

\section{2. 一般化異構造マスタスレーブシステム}

本節では，1.で述べた一般化異構造 MSS の構成例を 提案し, 少ない自由度の入力で多くの自由度を操作可能 であることを示す .

Fig. 1 に示すような二つのマスタアームと三つのス レーブアームをもつシステムを考える . マスタアームの 関節角速度を $\boldsymbol{\omega}=\left[\omega_{1}, \omega_{2}\right]^{\mathrm{T}}$, スレーブアームの関節角度 を $\boldsymbol{\theta}=\left[\theta_{1}, \theta_{2}, \theta_{3}\right]^{\mathrm{T}}$ とする .

まず第一，第二のスレーブアームについてはマスタ アームと同期した運動をさせることとし，以下のような

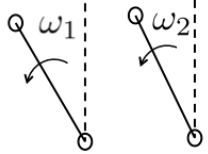

first arm second arm

master arms third arm

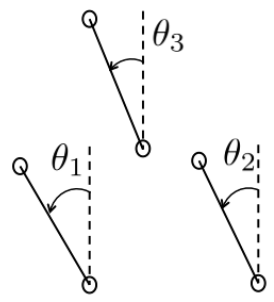

first arm second arm

slave arms
Fig. 1 2-master 3-slave manipulator system

状態方程式に従うものとする ${ }^{1}$.

$$
\left[\begin{array}{l}
\dot{\theta_{1}} \\
\dot{\theta_{2}}
\end{array}\right]=\left[\begin{array}{l}
\omega_{1} \\
\omega_{2}
\end{array}\right]
$$

さらに, 第三のスレーブアームの角度 $\theta_{3}$ と $\theta_{1}, \theta_{2}$ の間 に, 以下のような非ホロノミックな運動学的拘束条件を 課すことを考える．

$$
\dot{\theta}_{3}=\theta_{1} \dot{\theta}_{2}-\theta_{2} \dot{\theta}_{1}
$$

ここで, マスタアームの関節角速度 $\boldsymbol{\omega}=\left[\omega_{1}, \omega_{2}\right]^{\mathrm{T}}$ を制 御入力とし，関節角度 $\boldsymbol{\theta}=\left[\theta_{1}, \theta_{2}, \theta_{3}\right]^{\mathrm{T}}$ を状態とすると， このシステムは Brockett integrator とよばれる以下の 状態方程式で表される .

$$
\dot{\boldsymbol{\theta}}=\boldsymbol{G}(\boldsymbol{\theta}) \boldsymbol{\omega}
$$

$$
\begin{aligned}
\text { ただし }, g_{1}(\boldsymbol{\theta}), g_{2}(\boldsymbol{\theta}) \text { は } \\
\boldsymbol{G}(\boldsymbol{\theta})=\left[g_{1}(\boldsymbol{\theta}), g_{2}(\boldsymbol{\theta})\right] \\
g_{1}(\boldsymbol{\theta})=\left[\begin{array}{c}
1 \\
0 \\
-\theta_{2}
\end{array}\right], \quad g_{2}(\boldsymbol{\theta})=\left[\begin{array}{c}
0 \\
1 \\
\theta_{1}
\end{array}\right]
\end{aligned}
$$

である.ある状態 $\boldsymbol{\theta}=\theta_{0}$ で入力を与えたときに状態が 移動しうる方向は, 瞬間的にはべクトル場 $g_{1}\left(\theta_{0}\right), g_{2}\left(\theta_{0}\right)$ が張る平面

$$
\operatorname{span}\left\{g_{1}\left(\theta_{0}\right), g_{2}\left(\theta_{0}\right)\right\}
$$

内に限定される。しかしながら， $g_{1}, g_{2}$ から生成される Lie 括弧積

$$
\left[g_{1}, g_{2}\right](\boldsymbol{\theta})=\frac{\partial g_{2}}{\partial \boldsymbol{\theta}}(\boldsymbol{\theta}) g_{1}(\boldsymbol{\theta})-\frac{\partial g_{1}}{\partial \boldsymbol{\theta}}(\boldsymbol{\theta}) g_{2}(\boldsymbol{\theta})=\left[\begin{array}{l}
0 \\
0 \\
2
\end{array}\right]
$$

は任意の $\boldsymbol{\theta}$ において $g_{1}(\boldsymbol{\theta}), g_{2}(\boldsymbol{\theta})$ と線形独立であるた め, $\operatorname{span}\left\{g_{1}(\boldsymbol{\theta}), g_{2}(\boldsymbol{\theta}),\left[g_{1}, g_{2}\right](\boldsymbol{\theta})\right\}$ は常に $\boldsymbol{R}^{3}$ となる . し たがって , Chow の定理 [8] よりこのシステムは大域的に

\footnotetext{
ㄹ当然ながら，現実には角度偏差のフィードバックを行 う必要があるが，この議論では省略している。
} 
可制御であり，任意の初期状態から目標状態へ遷移させ る制御入力が存在する.すなわち周期入力などの適切な 入力によって微小時間後には任意の方向への状態遷移が 可能となる.

例として，以下のような $T=\pi / \sqrt{2}$ を 1 周期とする平 均 0 の周期入力を加えたときのシステム $(2)$ の状態変化 を考える。

$$
\left[\begin{array}{l}
\omega_{1}(t) \\
\omega_{2}(t)
\end{array}\right]=\left[\begin{array}{l}
\cos 2 \sqrt{2} t \\
\sin 2 \sqrt{2} t
\end{array}\right]
$$

文献 [9] より，上記のような周期入力を 1 周期加えるこ とによって生じる Lie bracket 運動方向への状態変化量 は, 入力 $\omega_{1}(t), \omega_{2}(t)$ の兰れ光れの時間積分 $\Omega_{1}(t), \Omega_{2}(t)$ が $\Omega_{1}-\Omega_{2}$ 平面で描く閉曲線の囲む面積 $A$ に比例した值 に近似できる .ここで, 入力の時間積分は以下の式で表 される.

$$
\left[\begin{array}{l}
\Omega_{1}(t) \\
\Omega_{2}(t)
\end{array}\right]=\left[\begin{array}{l}
\frac{1}{2 \sqrt{2}} \sin 2 \sqrt{2} t \\
-\frac{1}{2 \sqrt{2}} \cos 2 \sqrt{2} t
\end{array}\right]
$$

このとき, 上記の閉曲面が囲む領域は半径 $1 / 2 \sqrt{2}$ の円 となり，面積は $A=\pi / 8$ となる.よって 1 周期後の状態 ベクトルの変化は, 以下のように近似的に表される .

$$
\boldsymbol{\theta}(T)-\boldsymbol{\theta}(0) \simeq A\left[g_{1}, g_{2}\right](0)=\frac{\pi}{4}\left[\begin{array}{l}
0 \\
0 \\
1
\end{array}\right]
$$

このときの樣子を Fig. 2 に示す . 初期状態を $\boldsymbol{\theta}(0)=$ $[0,0,0]^{\mathrm{T}}$ として $t \in[0, T]$ で周期入力 (4) を加えると，ス レーブアームの各関節の時間応答はFig. 2(a)のように なる .1 周期後には第 1 , 第 2 のスレーブアームの状態 変数 $\theta_{1}(T), \theta_{2}(T)$ は初期值に戻るのに対し $\theta_{3}(T)=\pi / 4$ となって， $\theta_{3}$ の値だけを独立に操作することができる． また，(4) 式の振幅や周波数比，位相差を変えることに よって状態遷移を調整することができ，一般には非ホ口 ノミック系の制御問題に帰着される問題となる。

\section{3. 可操作性による一般化異構造 MSS の 操縦特性の特徵付け}

前節で示したような一般化異構造 MSS のように非ホ ロノミックな拘束をもつシステムの操作特性を定量的に 評価するため，本節では，マニピュレータの関節自由度 と手先自由度の運動学的関係の指標である可操作性 [10] の考え方を導入することを提案する．以下では, 非ホロ ノミック系の一つのクラスである対称アフィン系におけ る可操作性の意味付けと关の問題点について述へ，光の ような非ホロノミック系に対して適用できるように評価 指標を拡張することを提案する。

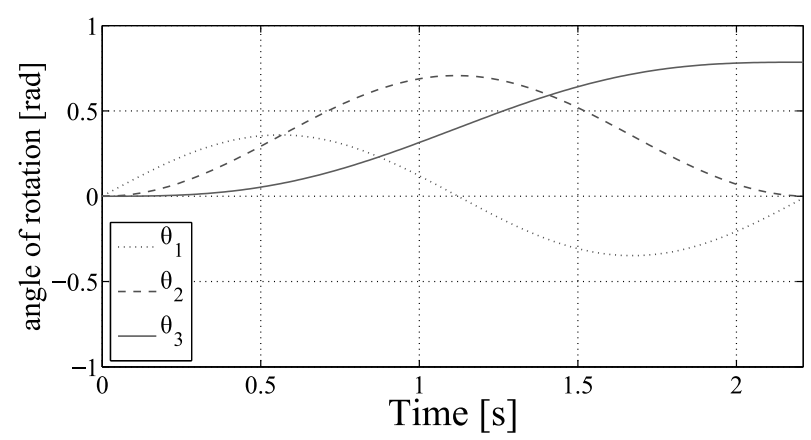

(a) Motion of arms vs. time

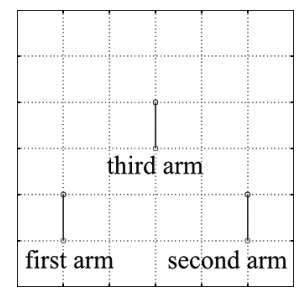

(b) $t=0$

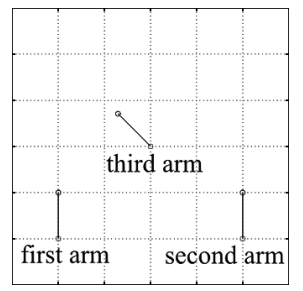

(c) $t=T$
Fig. 2 A motion sample of 2-master 3-slave manipulator system

\section{1 可操作性}

関節自由度が $n$, 手先自由度が $m$ を持つマニピュレー タを考える．一般には $m \leq n$ と仮定される．関節べク卜 ルを $\boldsymbol{q}=\left[q_{1}, q_{2}, \ldots, q_{n}\right]^{\mathrm{T}}$ ，先端の位置および姿勢を表すべ クトルを $\boldsymbol{r}=\left[r_{1}, r_{2}, \ldots, r_{m}\right]^{\mathrm{T}}$ とする. 両者の幾何学的関 係 (ホロノミック拘束) が

$$
r=\boldsymbol{f}(\boldsymbol{q})
$$

で与えられるとき， $\boldsymbol{r}$ に対応する速度べクトル $\dot{\boldsymbol{r}}$ と関節 速度 $\dot{q}$ の関係は $\boldsymbol{f}(\boldsymbol{q})$ のヤコビ行列 $\boldsymbol{J}(\boldsymbol{q})$ を用いて以下の 式で表される。

$$
\dot{\boldsymbol{r}}=\boldsymbol{J}(\boldsymbol{q}) \dot{\boldsymbol{q}}
$$

ここで関節角速度 $\dot{\boldsymbol{q}}$ が $\|\dot{\boldsymbol{q}}\| \leq 1$ を満たすときに実現し うる先端速度 $\boldsymbol{r}$ の集合を考えると，Fig. 3 に示すように主 軸方向の単位ベクトル $\boldsymbol{u} \in \boldsymbol{R}^{m}$, 主軸半径 $\sigma_{1}, \sigma_{2}, \ldots, \sigma_{m}$ で表される $m$ 次元空間の楕円体となり, 以下の式で与え られる。

$$
\dot{\boldsymbol{r}}^{\mathrm{T}}\left(\boldsymbol{J}^{+}\right)^{\mathrm{T}} \boldsymbol{J}^{+} \dot{\boldsymbol{r}} \leq 1 \quad \text { かつ } \quad \dot{\boldsymbol{r}} \in \boldsymbol{R}(\boldsymbol{J})
$$

ただし， $J^{+}$は $J$ の疑似逆行列であり， $R(J)$ は $J$ の値 域を表す .このようにして与えられる棈円体は可操作性 棈円体とよばれ, 产の主軸の長さはマニピュレータの姿 勢に対する先端の速度の出しやすさを表している .すな わち, 主軸半径の長い方向には他の方向に比へてて大きな 先端速度を実現することができ, 主軸半径の短い方向に は他の方向よりも小さな先端速度しか実現できない . 


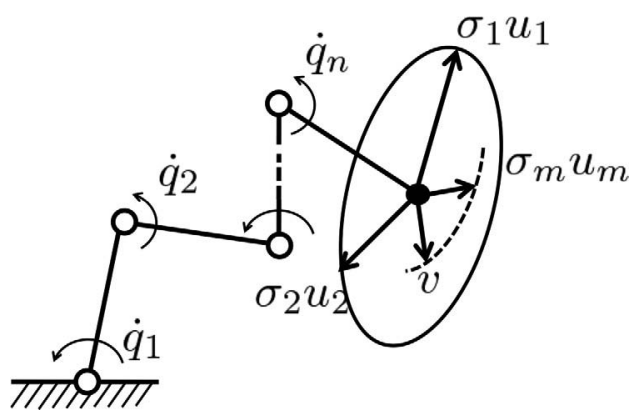

Fig. 3 Manipulability ellipsoid

可操作性楕円体から考えられる操作能力を一元化した 指標として代表的なものに，この楕円体の体積が考えら れる . 楕円体の体積は $\boldsymbol{J}(\boldsymbol{q})$ の特異値の積 $\sigma=\sigma_{1} \sigma_{2} \ldots \sigma_{m}$ に比例するので , この $\sigma$ をマニピュレータの姿勢 $q$ にお ける操作度とよゔ 。

このように定義された可操作度は, $\sigma=\sqrt{\operatorname{det} \boldsymbol{J}(\boldsymbol{q}) \boldsymbol{J}^{\mathrm{T}}(\boldsymbol{q})}$ とも表すことができ， $\sigma \geq 0$ をみたす．しかし，マニピュ レータが特異姿勢にあり $\operatorname{rank} \boldsymbol{J}(\boldsymbol{q})<m$ となるときには， 速度ベクトル $\dot{\boldsymbol{r}}$ に対してマニピュレータが瞬間的に移動 できない方向，すなわち楕円体の主軸の長さが 0 になる 方向が存在し， $\sigma=0$ となる．

\section{2 非ホロノミック系への適用可能性}

さて，2.で述べたように非ホロノミックな拘束を受け る運動学モデルの多くは, 以下のような対称アフィン系 とよばれる非線形状態方程式で表される.

$$
\dot{\xi}=\boldsymbol{G}(\boldsymbol{\xi}) \boldsymbol{v}
$$

ただし $\boldsymbol{\xi} \in \boldsymbol{R}^{n}$ は状態べクトル, $\boldsymbol{v} \in \boldsymbol{R}^{m}$ は入力であり， $\boldsymbol{G}$ は $\boldsymbol{R}^{n}$ から $\boldsymbol{R}^{n \times m}$ への行列值関数である . 一般には $m<n$ と仮定される .

ここで，(6) 式と (7) 式を形式的に対比すると，入力 $\boldsymbol{v}$ から状態の接べクトル $\dot{\boldsymbol{\xi}}$ への可操作性を考えることが できる．しかしながら，この場合は $m<n$ であること から $\operatorname{rank} G(\xi)<n$ であり，したがって可操作性楕円体

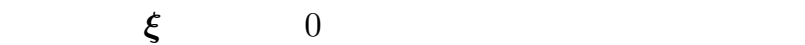
ンシステムでは状態を遷移させられる方向は瞬間的には $\operatorname{Im} G(\boldsymbol{\xi})$ で表される $m$ 次元部分空間に限られ，乥れ以 外の方向に関する可操作性楕円体の主軸は 0 になってし まっていることに起因する．よって，このままでは Lie 括弧積運動などの周期的な操作を用いた非局所的な状態 遷移の可能性を捉えることができていない．

そこで, 瞬間的な状態遷移だけではなく，時間的に微 小な幅をもった状態の到達領域を考慮できるように，可 操作性の概念を拡張することを考える . まず, 本来の可 操作性の定義における入力ノルムの正規化 $\|\dot{\boldsymbol{q}}\| \leq 1$ に相 当するものとして, 入力制約

$$
\boldsymbol{v}(\cdot) \in \Omega, \quad \Omega \subset C^{m}[0, \varepsilon]
$$

を想定する .ここで $C^{m}[0, \varepsilon]$ は $[0, \varepsilon] \subset \boldsymbol{R} て ゙$ 定義された $\boldsymbol{R}^{m}$ 値の連続関数の集合， $\Omega$ は关の何らかの部分集合で 許容入力集合とよゔ .

【定義 1】微小時間 $\varepsilon$ をパラメータとし，ある状態 $\boldsymbol{\xi}$ から，入力制約 (8) のもとで時刻 $\varepsilon$ までに到達しうる状 態の集合を $\boldsymbol{\xi}$ における $\varepsilon$-可到達領域とよび, $\mathcal{R}_{\leq \varepsilon}(\boldsymbol{\xi})$ と 表す.

可到達領域の概念乥のものは非線形制御理論においては よく知られたものであるが, 本研究では, 一般化異構造 MSSの可操作性をとの状態における $\varepsilon$-可到達領域をもつ て特徵付けることを提案する．とを陽に含んだ表現であ ること, 方向による状態の操作しやすさが可到達領域の 形状に反映されていること ${ }^{1}$, 乥して許容入力集合 $\Omega$ に よってある一定範囲の入力のもとでの操作能力を表して いる点が特徵である．これにより，たとえば複数の MSS の可操作性を同一の $\varepsilon$ と に対する可到達領域の体積や 方向ごとの外径によって比較することができる . 従来の 可操作性楕円体は $\varepsilon=0, \Omega=\{\boldsymbol{v} \mid\|\boldsymbol{v}(0)\| \leq 1\}$ とおいた 特別な場合として含まれる．

本研究においてはこの概念を, 準大域的可操作性とよ ぶこととし，初期状態から時間 $\varepsilon$ の間に状態が到達でき る領域を準大域的可到達領域とよゔ.

\section{4. $\varepsilon$-可到達領域の解析法}

前節で提案した $\varepsilon$-可到達領域の定義は対称アフィン系 (7) をはじめ一般の非線形システムに対して適用可能で あるが, 弚の具体的な算出は一般には容易ではない . と くに $\mathcal{R}_{\leq \varepsilon}(\boldsymbol{\xi})$ を $\varepsilon, \boldsymbol{\xi}$ をパラメータとして陽に表現するこ とは困難であり，簡便な計算方法が求められる .

そこで本節では, 許容入力 $\Omega$ を周波数および位相でパ ラメータづけした周期入力の集合とし，数值計算によっ て比較的簡単に光の概形を求める方法を提案する . 光 の有効性を確認するために， $\mathcal{R}_{\leq \varepsilon}(\mathbf{0})$ の解析解がすでに 知られている例として Brockett integrator をとりあげ， 解析解と数值解との比較を検討する.

4.1 準大域的可到達領域の解析解之適用可能性 以下に示す対称アフィンシステムは Brockett integrator とよばれ，大域的に可制御な非ホロノミックシステ ムの典型例である .

$$
\left[\begin{array}{l}
\dot{\xi}_{1} \\
\dot{\xi}_{2} \\
\dot{\xi}_{3}
\end{array}\right]=\left[\begin{array}{cc}
1 & 0 \\
0 & 1 \\
-\xi_{2} & \xi_{1}
\end{array}\right]\left[\begin{array}{l}
v_{1} \\
v_{2}
\end{array}\right]
$$

なお，前述した (2) 式も Brockett integrator にほかなら ず, $\theta_{i}$ と $\xi_{i}, \omega_{i}$ と $v_{i}$ が光れ光れ対応している.

ここで, 入力制約としては

$$
\Omega=\{\boldsymbol{v}(\cdot) \mid\|\boldsymbol{v}(t)\| \leq 1, t \in[0, \varepsilon]\}
$$

\footnotetext{
${ }^{1}$ 対称アフィンシステム $(7)$ が局所可制御であれば $\varepsilon>0$

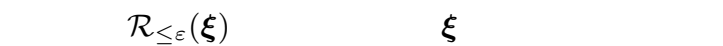



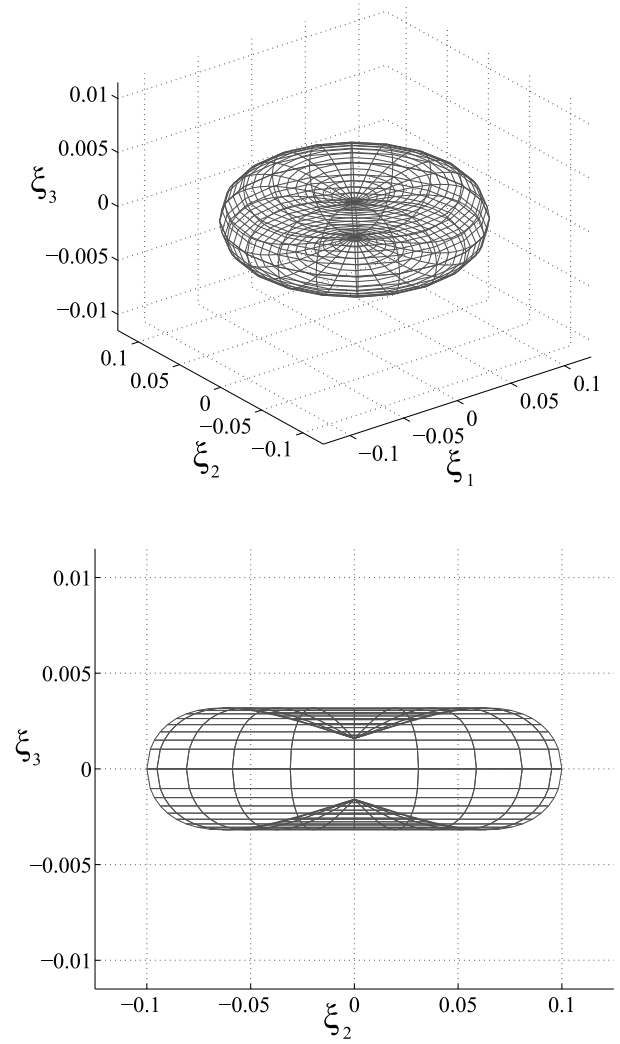

Fig. 4 Analytical solution of $\varepsilon$-reachable area from the origin of Brockett integrator

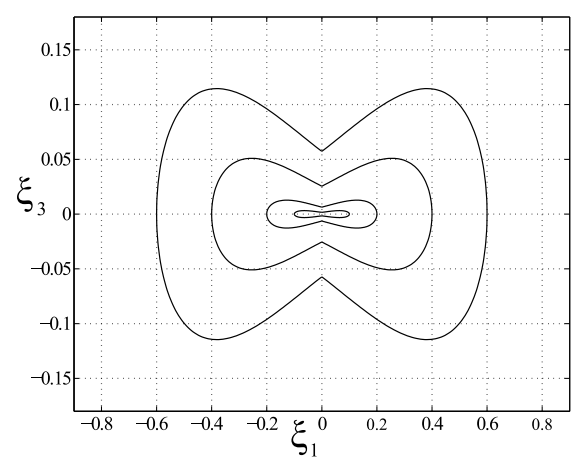

Fig. 5 Analystic solutions with respect to various $\varepsilon$ s

\section{を考える}

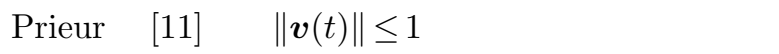
限時間で原点に到達可能な初期状態の領域を陽に示した が , この結果は $\mathcal{R}_{\leq \varepsilon}(\mathbf{0})$ の解析解にほかならない. 具体 的には, 媒介変数 $\psi \in[0, \pi], \alpha \in[0,2 \pi)$ を用いて以下の 式で表される閉曲面と谷の内部である .

$$
\left\{\begin{array}{l}
\xi_{1}(\varepsilon)=\frac{\sin \psi}{\psi} \varepsilon \cos \alpha \\
\xi_{2}(\varepsilon)=\frac{\sin \psi}{\psi} \varepsilon \sin \alpha \\
\xi_{3}(\varepsilon)= \pm \frac{\psi-\sin \psi \cos \psi}{2 \psi^{2}} \varepsilon^{2}
\end{array}\right.
$$

$\varepsilon=0.1$ としたとき，この解析解が表す領域を Fig. 4 に 示す.また， $\varepsilon=0.1,0.2,0.4,0.6$ において原点を通る
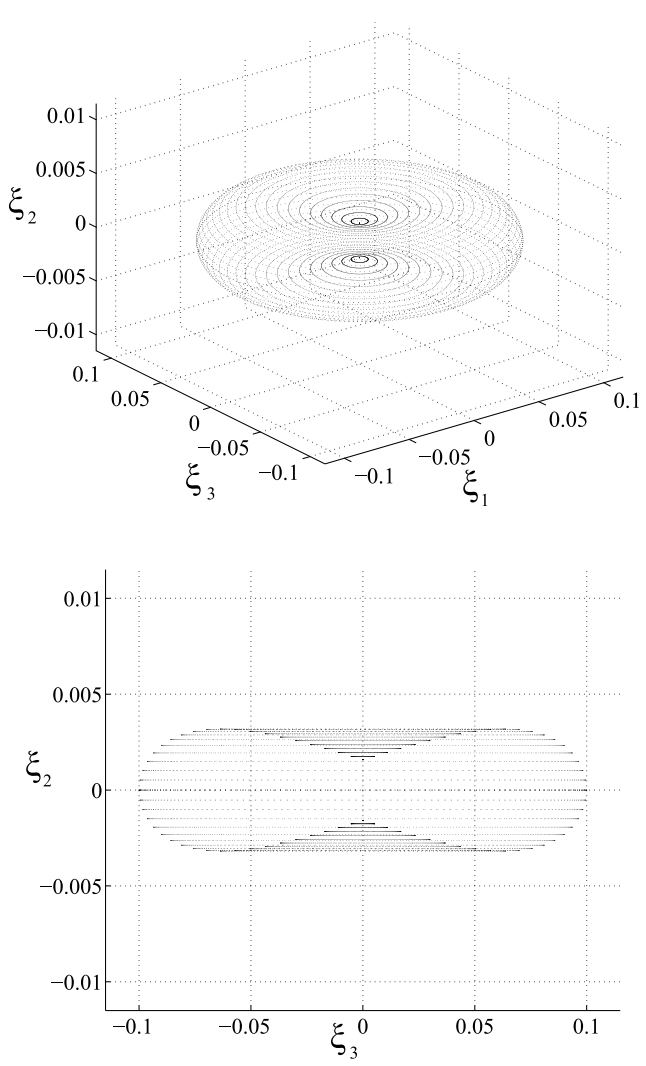

Fig. 6 Numerical approximation of $\varepsilon$-reachable area from the origin of Brockett integrator

$\xi_{1}-\xi_{3}$ 平面による断面の形を Fig. 5 に示した .

Fig. 5 より， $\varepsilon$-可到達領域が微小時間 $\varepsilon$ に対して単調 に拡大している樣子がわかる .また (11) 式によれば，1 階のLie括弧積の方向である $\xi_{3}$ 軸方向への大きさは $\varepsilon$ の 2 乗に比例して増加するが , このことも Fig. 5 において $\varepsilon$ に対する形状の推移として反映されている.

\section{2 フーリエ級数展開による数值近似}

$\mathcal{R}_{\leq \varepsilon}(\boldsymbol{\xi})$ を数值的に求める準備として，区間 $[0, \varepsilon] に お ~$ いてフーリエ級数展開可能な入力

$$
\left\{\begin{array}{l}
v_{1}(t)=a_{10}+\sum_{k=1}^{\infty}\left(a_{1 k} \cos k \omega t+b_{1 k} \sin k \omega t\right) \\
v_{2}(t)=a_{20}+\sum_{k=1}^{\infty}\left(a_{2 k} \cos k \omega t+b_{2 k} \sin k \omega t\right)
\end{array}\right.
$$

を加えたときの到達状態を陽に計算してみる。ただし $a_{i j}, b_{i j}, i \in\{1,2\}, j \in\{0,1, \cdots\}$ は光れ実定数であ り, $v_{1}(t), v_{2}(t)$ は周期 $\varepsilon$ の周期関数すなわち $\omega \varepsilon=2 \pi$ を 仮定する .この入力のもとでは, 状態方程式の時間積 分を以下のように直接求めることができる(これは文 献 [12]の, 正弦波入力を級数展開の形に拡張した結果に あたる) 。 


$$
\left\{\begin{aligned}
\xi_{1}(\varepsilon)= & \xi_{1}(0)+a_{10} \varepsilon \\
\xi_{2}(\varepsilon)= & \xi_{2}(0)+a_{20} \varepsilon \\
\xi_{3}(\varepsilon)= & \xi_{3}(0)+\left|\begin{array}{ll}
\xi_{1}(0) & a_{10} \\
\xi_{2}(0) & a_{20}
\end{array}\right| \\
& +\frac{1}{2 \pi} \sum_{k=1}^{\infty} \frac{1}{k}\left|\begin{array}{ll}
a_{1 k}-2 a_{10} & b_{1 k} \\
a_{2 k}-2 a_{20} & b_{2 k}
\end{array}\right| \varepsilon^{2}
\end{aligned}\right.
$$

以上より, 状態の変化分は初期状態と直流成分に比例 した係数をもつ の一次項と， $\xi_{3}$ 方向のみに関して周波 数に反比例した幕級数の係数をもつ ことが定量的に示された．したがって，もし $\mathcal{R}_{\leq \varepsilon}(\boldsymbol{\xi})$ を 近似的に求める場合, 比較的低周波数の成分で打ち切っ ても影響は少ないことが予想される .ただし (12)式の形 の入力は , 多数の係数パラメータを含むことから入力制 限 $\Omega$ を定式化することが困難である．乥こで次小節で は，位相パラメータを併用し周期 $\varepsilon$ とは限らない入力集 合を用いることで, 比較的容易に $\mathcal{R}_{\leq \varepsilon}(\boldsymbol{\xi})$ の数值近似解 を求める方法を提案する.

4.3 位相パラメータを併用した数值近似解

前小節と同樣に $\omega \varepsilon=2 \pi$ とし，周波数比 $f$ ，初期位相 $\phi$ をパラメータとしたつぎのような入力集合を考える .

$$
\Omega^{\prime}=\left\{\boldsymbol{v}(\cdot) \mid \boldsymbol{v}(t)=\left[\begin{array}{c} 
\pm \sin (f \omega t+\phi) \\
\cos (f \omega t+\phi)
\end{array}\right], t \in[0, \varepsilon],\right.
$$

つねに $\|\boldsymbol{v}(t)\| \equiv 1$ であるので，これが $(10)$ 式で用い た入力制限 $\Omega$ を満たしていることは明らかである .この 入力 (14) を前小節で用いたフーリ工級数展開の枠組みと 関連づけておこう . (14) 式を $t \in[0, \varepsilon]$ でフーリエ級数展 開すると

$$
\begin{aligned}
{\left[\begin{array}{l}
v_{1}(t) \\
v_{2}(t)
\end{array}\right] } & =\boldsymbol{A}_{n}+\boldsymbol{B}_{n}\left[\begin{array}{c}
\cos n \omega t \\
\sin n \omega t
\end{array}\right] \\
\boldsymbol{A}_{n} & =\frac{1}{2 \pi f}\left[\begin{array}{l}
-\Delta C_{f \phi} \\
\Delta S_{f \phi}
\end{array}\right] \\
\boldsymbol{B}_{n} & =-\frac{1}{\pi} \frac{1}{n^{2}-f^{2}} \sum_{n=1}^{\infty}\left[\begin{array}{ll}
f \Delta C_{f \phi} & n \Delta S_{f \phi} \\
f \Delta S_{f \phi} & n \Delta C_{f \phi}
\end{array}\right]
\end{aligned}
$$

ただし

$$
\left[\begin{array}{c}
\Delta C_{f \phi} \\
\Delta S_{f \phi}
\end{array}\right]=\left[\begin{array}{c}
\cos (2 \pi f+\phi)-\cos (\phi) \\
\sin (2 \pi f+\phi)-\sin (\phi)
\end{array}\right]
$$

となる . (15) 式より，入力 (14) は低周波成分を多分に含 み，4.2で計算を行った状態到達点を近似するのに適し ていることが確認できる .

ここで入力集合として ,(14) 式の $\Omega^{\prime}$ から有限個の要 素を選んだ

$$
\Omega^{\prime}=\left\{\boldsymbol{v}(\cdot) \mid \boldsymbol{v}(t)=\left[\begin{array}{c} 
\pm \sin (f \omega t+\phi) \\
\cos (f \omega t+\phi)
\end{array}\right], t \in[0, \varepsilon],\right.
$$

$$
f \in\{0,0.05, \cdots, 1.0\}, \phi \in\{-\pi,-0.99 \pi, \ldots, \pi\}\}
$$

を用い, $\varepsilon=0.1$ で状態が到達した点を数值計算すること によって $\mathcal{R}_{\leq \varepsilon}(\mathbf{0})$ の近似を求めた結果がFig. 6 である.

前述した解析解 (Fig. 4) と数值近似解 (Fig. 6) を比 較すると，4000 点程度の計算にもかかわらず近似解が $\mathcal{R}_{\leq \varepsilon}(\mathbf{0})$ の概形をよく表していることがわかる . よって， この方法は可到達領域の解析解を求めるのが困難なシス テムにおいても，弚の概形を求める手段として有用であ ると期待できる .

\section{4 初期状態との関係}

最後に, 初期点が原点以外の状態に対する $\varepsilon$-可到 達領域の数值近似解を提案法によって求め, Brockett integrator の操作特性について考察を行う. $\varepsilon=1$ とし， 初期状態 $\boldsymbol{\xi}_{d 1}=[0.1,0,0]^{\mathrm{T}}, \boldsymbol{\xi}_{d 2}=[-0.1,0,0]^{\mathrm{T}}$ に対し $\tau, \mathcal{R}_{\leq \varepsilon}\left(\boldsymbol{\xi}_{d 1}\right), \mathcal{R}_{\leq \varepsilon}\left(\boldsymbol{\xi}_{d 2}\right)$ の近似を前節と同樣の数値計

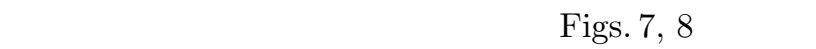

Fig. 7 より，初期状態 $\boldsymbol{\xi}_{d 1}$ では $\xi_{2}$ に対して正比例する 形状に可到達領域が変化している．すなわち，初期状態 $\boldsymbol{\xi}_{d 1}$ では状態 $\xi_{2}, \xi_{3}$ を同時に増減させることが容易である ものの, 片方を増加, 他方を減少させるという操作が困 難になる . 一方 Fig. 8 より，初期状態 $\boldsymbol{\xi}_{d 2}$ では領域が $\xi_{2}$ に対して負の比例する形状となる . すなわち, 初期状態 $\boldsymbol{\xi}_{d 1}$ とは対称に， $\xi_{2}, \xi_{3}$ を対称に増減させることが容易と なり，両者を同時に増減させることが困難となる．

以上の結果を $(2)$ 式にあてはめて考えるなら， $\varepsilon$-可到 達領域 $\mathcal{R}_{\leq \varepsilon}(\boldsymbol{\xi})$ は，拘束条件 (1)のもと第一，第二のス レーブアームの初期姿勢の影響を受けて準大域的可操作 性が変化し，間接的に操作を行う第三のスレーブアーム の操作性に影響が生じるということを意味している．す なわち，第一のスレーブアームの状態 $\theta_{1}$ が正の値をと るとき $\left(\boldsymbol{\xi}_{d 1}\right.$ の状態に相当する ) には，第二と第三のス レーブアームをともに同方向に遷移させる操作が容易で ある一方，互いに対称な方向への操作は困難であること を表している.一方で， $\theta_{1}$ が負の值をとるとき $\left(\boldsymbol{\xi}_{d 2}\right.$ の 状態に相当する），今度は第二，第三のスレーブアーム がともに同方向へ遷移することが困難になり，異方向へ の遷移が容易となる .

以上より，提案法を用いて Brockett integrator の準 大域的可操作性を求めることで, 入出力の対応や状態変 数の拘束条件により規定されるシステム特有の操作特性 の一部を， $\varepsilon$-可到達領域の形状から視覚的に捉えること が可能となった .

\section{5. おわりに}

本論文では，非ホロノミック拘束を導入することに よって操作自由度の増大をも可能にした MSS を一般化 異構造 MSS として提案した . また, 谷の操縦特性を評 価するための指標である可操作性の概念の拡張として， 微小な制御時間 $\varepsilon$ をパラメータに残した形で, 許容入力 

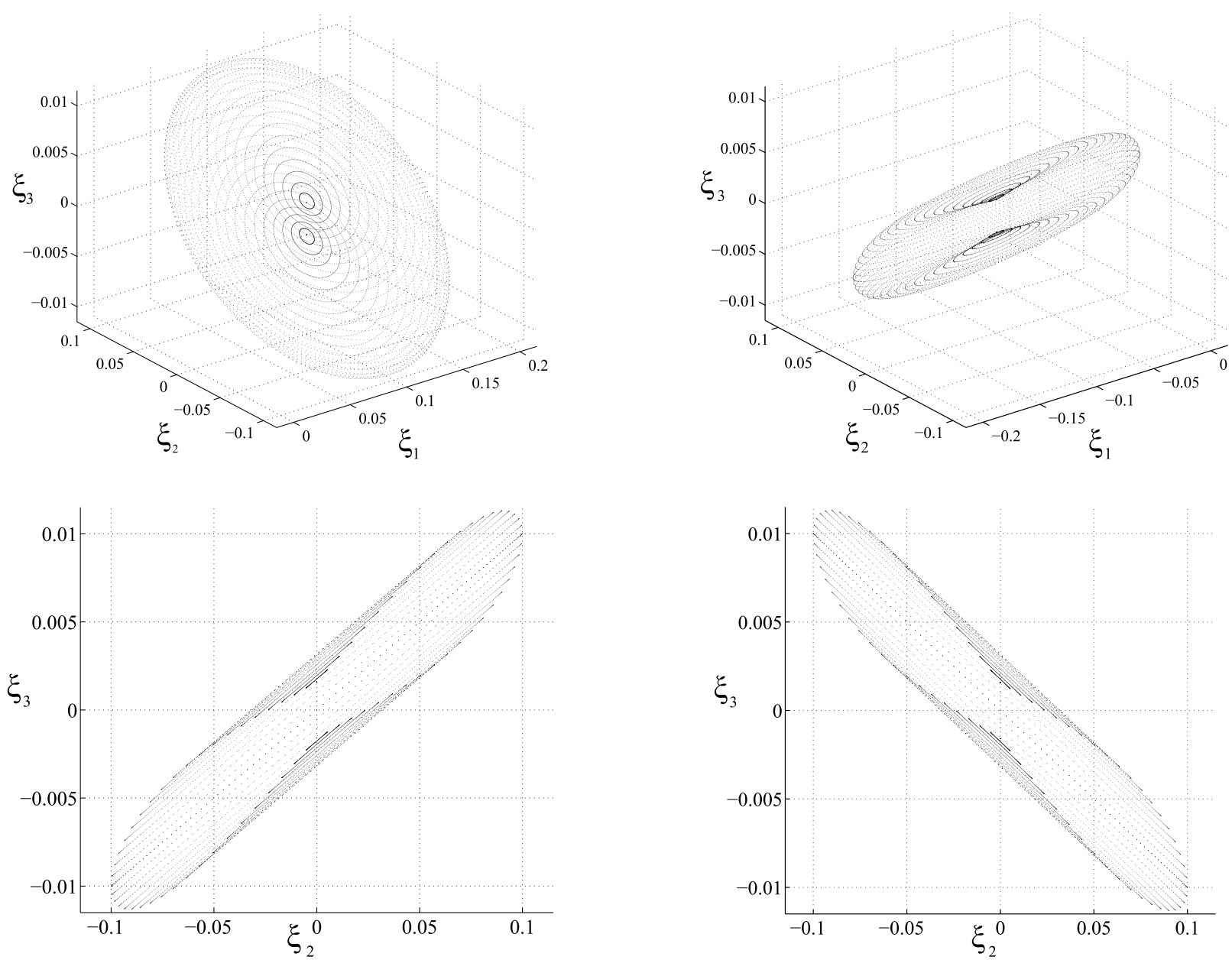

Fig. $7 \quad \varepsilon$-reachable area from $\boldsymbol{\xi}_{d 1}$

Fig. $8 \varepsilon$-reachable area from $\boldsymbol{\xi}_{d 2}$

\section{参考文 献}

$\Omega$ のもとでの状態空間の $\varepsilon$-可到達領域を一般化異構造 MSS における可操作性の指標として用いることを提案 した . また非ホロノミック系の典型例である Brockett integrator に対して，時刻 $\varepsilon$ までのフーリ工級数展開で 表される入力下での可到達領域を求め, 状態の初期值, 入力の定数成分および調和成分に依存する形で定量的に 表した .この知見に基づき，位相パラメータを併用した 許容入力集合のパラメータ付けにより $\varepsilon$-可到達領域の概 形を比較的容易に数值近似する方法を提案した .またこ の方法を用いてシステムの可操作性について考察した .

今後の課題として, 従来の可操作棈円体の体積のよう に，可操作性を集約した数值指標を考案することが挙げ られる.一つの考え方は $\varepsilon$-可到達領域の体積を光のまま 採用することであるが，光れでは計算が困難なうえに方 向ごとに異なる操作のしやすさを反映することができな い. 可到達領域を複数の楕円体で近似して兴の特異值を 用いるなど，有用かつ簡便に表現する方法が求められる .

\section{謝辞}

本研究の一部は文部科学省科学研究費補助金基盤研究 (C)No.22560445により行われた .ここに謝意を表する .

[1] 美多 : 非線形制御入門，昭晃堂 (2000)

[2] 荒井 : 非ホロノミック系操作のためのヒューマンイン ターフェース ; 日本ロボット学会誌, Vol. 21, No. 5, pp. 554-561 (2003)

[3] M. Ishikawa: Reduction of control inputs for multiple mobile robots; Proc. of the 18th IFAC World Congress, pp. 11881-11886 (2011)

[4] 中村, Sørdalen, 鄭: 非ホロノミック・マニピュレータの 理論的設計と非線形制御; 日本ロボット学会誌, Vol. 13, No. 5, pp. 674-682 (1995)

[5] 中村, 鄭, Sørdalen : 非ホロノミック・マニピュレータ の実験的研究; 日本ロボット学会誌, Vol. 14, No. 5, pp. 694-702 (1996)

[6] 尾崎, 下川, 吉永 : 異構造マスタスレーブアームの制御 器設計 -特異姿勢回避- ; 日本機械学会九州支部総会講演 論文集, pp. 237-238 (2008)

[7] 舘, 川上 : テレイグジスタンスの研究 (第 57 報) -簡 易型マスタシステム"MeisterGRIP" の設計 ; 日本バー チャルリアリティ学会第 13 回大会論文集 $(2008)$

[8] H. Nijmeijer and A. J. van der Schaft: Nonlinear Dynamical Control Systems, Springer (1990)

[9] 石川 : 三叉へビ型ロボットの推進原理と周期入力によ 
る制御; 計測自動制御学会論文集, Vol. 42, No. 5 , pp. 520-528 (2006)

[10] 吉川 : ロボット制御基礎論 , コロナ社 (1988)

[11] C. Prieur and E. Trélat: Robust optimal stabilization of the brockett integrator via a hybrid feedback; Mathematics of Control, Signals, and Systems, Vol. 17, No. 3, pp. 210-216 (2005)

[12] R. M. Murray and S. S. Sastry: Nonholonomic motion planning: Steering using sinusoids; IEEE Trans. on Automatic Control, Vol. 38, No. 5, pp. 700-716 (1993)

[13] 伊達, 田原, 三平 : 1 ロータ姿勢制御系の可到達領域の数 值的評価 ; 第 40 回制御理論シンポジウム, SICE (2011)

\section{著者略歴}

岸照邦䇪

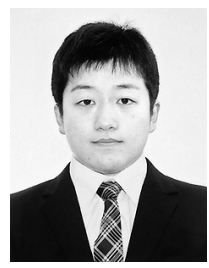

2011 年大阪大学工学部応用理工学科卒 業, 同年大阪大学大学院工学研究科機械 工学専攻に入学し現在に至る.非線形制 御, 非ホロノミックシステム, ロボティク スなどの研究に従事.日本機械学会の学生 会員.

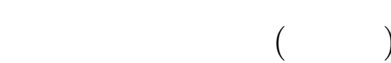

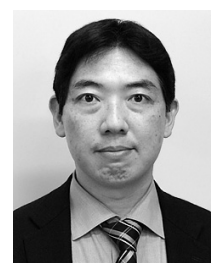

1994 年東京工業大学工学部制御工学科 卒業, 2000 年同大学院情報理工学研究科 博士後期課程修了. 同大学助手, 東京大学 情報理工学系研究科助手, 京都大学情報学 研究科講師を経て, 2010 年大阪大学工学 研究科機械工学専攻准教授となり現在に至 る.非線形制御 , 非ホロノミックシステム , ロボティクスな どの研究に従事. 博士 (工学) . 計測自動制御学会 , 日本口 ボット学会, 日本機械学会, IEEEの会員.

\section{势須賀公穴 (正会員)}

1984 年大阪大学大学院基礎工学研究科

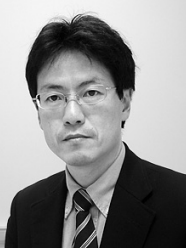
修士課程 (制御工学) 修了. 同年 (株) 東芝 入社, 総合研究所勤務. 1986 年大阪府立 大学工学部助手. 炎の後, 講師, 助教授, 京都大学大学院情報学研究科助教授, 神戶 大学工学部教授を経て，2009 年大阪大学 大学院工学研究科機械工学専攻教授となり現在に至る.ロボ ティクス, 制御工学, レスキュー工学などの研究に従事.工 学博士. IEEE, 計測自動制御学会, 日本機械学会, 日本口 ボット学会などの会員 . 